Notas Científicas

\title{
Biology and parasitic potential of Doryctobracon areolatus on Anastrepha fraterculus larvae
}

\author{
Adrise Medeiros Nunes(1), Dori Edson Nava(2), Fernanda Appel Müller ${ }^{(1)}$, \\ Rafael da Silva Gonçalves ${ }^{(1)}$ and Mauro Silveira Garcia( ${ }^{(1)}$
}

\begin{abstract}
(1)Universidade Federal de Pelotas, Faculdade de Agronomia Eliseu Maciel, Departamento de Fitossanidade, Caixa Postal 354, CEP 96010-900 Pelotas, RS, Brazil. E-mail: adrisenunes@gmail.com, fe.muller1981@yahoo.com.br, rafaeldasilvagoncalves@gmail.com, garciasmauro@yahoo.com.br (2)Embrapa Clima Temperado, Laboratório de Entomologia, BR 392, Km 78, Caixa Postal 403, CEP 96001-970 Pelotas, RS, Brazil. E-mail: nava.dori@cpact.embrapa.br
\end{abstract}

\begin{abstract}
The objective of this work was to study the biology and parasitic potential of Doryctobracon areolatus on larvae of Anastrepha fraterculus. The egg-adult period, the sex ratio, the longevity, the pupal viability, and the parasitism rate of $D$. areolatus were determined in laboratory, using $A$. fraterculus as host. The parasitoid development from oviposition to adult emergence required $25.00 \pm 1.70$ days, the sex ratio was $0.62 \pm 0.09$, and the mean longevity was $16.36 \pm 3.62$ days for males and $10.24 \pm 1.71$ days for females. The mean parasitism rate was $53.50 \pm 8.93 \%$, varying from 41.60 to $68.60 \%$, which shows the potential of this parasitoid for biological control of $A$. fraterculus.

Index terms: biological control, Braconidae, parasitism rate, South American fruit fly.

\section{Biologia e potencial de parasitismo de Doryctobracon areolatus em larvas de Anastrepha fraterculus}

Resumo - O objetivo deste trabalho foi estudar a biologia e o potencial de parasitismo de Doryctobracon areolatus em larvas de Anastrepha fraterculus. Foram determinados em laboratório: a duração do período ovo-adulto, a razão sexual, a longevidade, a viabilidade pupal, e o índice de parasitismo, tendo-se utilizado A. fraterculus como hospedeiro. O desenvolvimento do parasitoide, da oviposição à emergência do adulto, foi de $25,00 \pm 1,70$ dias, a razão sexual foi de $0,62 \pm 0,09$, e a longevidade média foi de $16,36 \pm 3,62$ dias para machos e 10,24 $\pm 1,71$ dias para fêmeas. O parasitismo médio foi de $53,50 \pm 8,93 \%$, tendo variado de 41,60 a $68,60 \%$, o que mostra o potencial deste parasitoide para o controle biológico de A. fraterculus.
\end{abstract}

Termos para indexação: controle biológico, Braconidae, taxa de parasitismo, mosca-das-frutas sul-americana.

Fruit flies (Diptera: Tephritidae) are the principal pests of fruit crops. They cause economic losses due to damaged fruit and quarantine restrictions which prevent fruit from being exported (Aluja, 1994). Fruit flies are normally controlled with chemical products, the use of which is becoming more restricted, mainly because of concern for the residues left in and on the fruit. Integrated pest management has become more popular in recent years, with emphasis on control methods that have less impact on humans and the environment, such as biological control (Norris et al., 2003).

Brazil has recently begun to investigate the biological control of fruit flies. Most studies concerned native parasitoids of the Braconidae and Figitidae families, and carried out faunistic analyses and examined their occurrence, distribution, behavior and taxonomy
(Leonel et al., 1995; Salles, 1996; Canal \& Zucchi, 2000; Guimarães \& Zucchi, 2004; Silva et al., 2007). There is practically no information on the biology of this parasitoid, although it is necessary for the development of biological control programs.

Among the species of parasitoids, Doryctobracon areolatus (Szépligeti) (Hymenoptera: Braconidae) stands out, as it is widely distributed in the Neotropical region, from Mexico to Argentina (Wharton \& Marsh, 1978). It is found throughout Brazil, where it parasitizes several species of fruit flies on various fruiting plants (Canal \& Zucchi, 2000).

The objective of this work was to study the biology and parasitic potential of $D$. areolatus on larvae of Anastrepha fraterculus (Wiedemann) (Diptera: Tephritidae) reared on papaya. 
The experiment was carried out in laboratory, under controlled temperature $\left(25 \pm 2^{\circ} \mathrm{C}\right)$, air relative humidity $(\mathrm{RH})$ of $70 \pm 10 \%$ and photophase of 12 hours. The fruit flies were obtained from a culture maintained in the Laboratório de Entomologia da Embrapa Clima Temperado. The parasitoids were collected from strawberry guava (Psidium cattleyanum Sabine) fruits infested by $A$. fraterculus, and were kept in the laboratory, for three generations, on $A$. fraterculus larvae reared on papaya fruit. The larvae were fed with $30 \%$ honey solution in a small container $(10 \mathrm{~mL})$. The papayas were placed in cages containing $50 \mathrm{~A}$. fraterculus female, approximately 15 days old, ready for oviposition. After 24 hours, the fruit were removed from the cages and kept in a climate-controlled room for five days, after which they were exposed to D. areolatus (Salles, 2000).

Five cages were used, each one containing 30 pairs of 6-day-old $D$. areolatus. Two papayas infested with first-instar larvae of $A$. fraterculus were exposed to the parasitoids in each cage. After 24 hours, the papaya fruit were removed from the cages and maintained in plastic boxes $(11 \times 12 \times 19 \mathrm{~cm})$ containing fine-grained vermiculite, in order to absorb excess humidity and allow pupation. The boxes had a mesh cover and were maintained in a climate-controlled room, under the same conditions described above, until pupae appeared. The pupae were collected daily and maintained in Petri dishes until they emerged.

The egg-adult development period, the sex ratio, the longevity of the males and females, the parasitism rate and pupal survival were determined for $D$. areolatus. The sex ratio (rs) was calculated using the equation $\mathrm{rs}=$ number of females/(number of females + number of males). The parasitism rate (P) was calculated using the equation $\mathrm{P}(\%)=$ number of emerged parasitoids x 100/(number of emerged flies + number of emerged parasitoids), and the pupal viability (PV) (percentage of emergence) was determined using the equation PV $(\%)=[$ (number of parasitoids + number of emerged flies) x 100]/total number of puparia.

The longevity of males and females was determined using 25 pairs, which were placed in glass tubes $(2.5 \times 8.5 \mathrm{~cm})$. Honey was offered as food, and was placed inside the tube by means of a scalpel; the tubes were maintained in a climate chamber $\left(25 \pm 2^{\circ} \mathrm{C}\right.$, $70 \pm 10 \% \mathrm{RH}$, and photophase of 12 hours), and the mortality of the flies was recorded daily.
The mean duration of the egg-adult development period of $D$. areolatus was $25.00 \pm 1.70$ days. This is a longer period than the previously reported for this species by Eitam et al. (2003), who observed a development time of 22.10 days for females and 20.60 days for males reared at the same temperature. However, they used larvae of Anastrepha suspensa (Loew) as hosts. Also, they used second-instar larvae, while the present study used first-instar larvae because, at $25^{\circ} \mathrm{C}$, the larvae would be near the end of the first instar, five days after oviposition (Salles, 2000). These contrasting results indicate that both the species and the larval stage of the host may affect the development time.

The $D$. areolatus sex ratio was $0.62 \pm 0.09$, indicating a greater proportion of females, which is an advantage for parasitoids. A similar ratio was found for $D$. areolatus reared on larvae of $A$. suspensa; however, the number of male descendants increased as infestation progressed (Eitam et al., 2003). For biological control programs, a sex ratio closer to 1 , indicative of a larger number of females in the population, is essential because the females are the parasitic agents.

The mean longevity was $16.36 \pm 3.62$ days for males and $10.24 \pm 1.71$ days for females. Information related to $D$. areolatus longevity was not found in literature.

The survival of $A$. fraterculus pupae reared on papaya and parasitized by $D$. areolatus in the larval stage was $84.86 \pm 7.81 \%$, varying from 69 to $96 \%$. The mean percentage of parasitism by $D$. areolatus in $A$. fraterculus larvae was $53.50 \pm 8.93 \%$, varying from 41.6 to $68.6 \%$, which shows the potential of this parasitoid for control of this pest. The percentage of parasitism is close to that recorded under natural conditions in Myrtaceae fruit, in which the parasitism levels were $63.4 \%$ in Syzygium aqueum (Burm), $44.6 \%$ in Eugenia dodoneifolia Cambess, $42.8 \%$ in P. cattleyanum, $34.8 \%$ in Eugenia sp., and $32.3 \%$ in Marlierea edulis (Berg) (Souza Filho, 1999). Garcia \& Corseuil (2004) also observed that among fruit-bearing plants, Myrtaceae species infested with $A$. fraterculus had the highest rates of parasitism (79.6\%). Although papaya, which was the fruit used as a substrate in the present study, is not preferred by $A$. fraterculus under field conditions (Nascimento et al., 2000), it is used for rearing South American fruit flies in the laboratory because it allows completion of larval development without the need to change the substrate. 
The mean of $53.5 \%$ parasitism of $D$. areolatus on A. fraterculus, found in the present study shows the potential for the use of this parasitoid in biological control programs. However, further studies are needed to discover ways to increase this proportion, such as improving techniques for rearing the parasitoid, and the use of semiochemicals.

\section{Acknowledgements}

To Dr. Valmir Antonio Costa, of Instituto Biológico, Agência Paulista de Tecnologia dos Agronegócios, Secretaria de Agricultura e Abastecimento, for identifying $D$. areolatus; and to Conselho Nacional de Desenvolvimento Científico e Tecnológico, for financing part of the project and for grants.

\section{References}

ALUJA, M. Bionomics and management of Anastrepha. Annual Review of Entomology, v.39, p.155-178, 1994.

CANAL, D.N.A.; ZUCCHI, R.A. Parasitóides - Braconidae. In: MALAVASI, A.; ZUCCHI, R.A. (Ed.). Moscas-das-frutas de importância econômica no Brasil: conhecimento básico e aplicado. Ribeirão Preto: Holos, 2000. p.119-126.

EITAM, A.; HOLLER, T.; SIVINSKI, J.; ALUJA, M. Use of host fruit chemical cues for laboratory rearing of Doryctobracon areolatus (Hymenoptera: Braconidae), a parasitoid of Anastrepha spp. (Diptera: Tephritidae). Florida Entomologist, v.86, p.211-216, 2003.

GARCIA, F.R.M.; CORSEUIL, E. Native hymenopteran parasitoids associated with fruit flies (Diptera: Tephritidae) in Santa Catarina state, Brazil. Florida Entomologist, v.87, p.517-521, 2004.
GUIMARÃES, J.A.; ZUCCHI, R.A. Parasitism behavior of three species of Eucoilinae (Hymenoptera: Cynipoidea: Figitidae) fruit fly parasitoids (Diptera) in Brazil. Neotropical Entomology, v.33, p.217-224, 2004.

LEONEL JUNIOR, F.L.; ZUCCHI, R.A.; WHARTON, R.A. Distribution and tephritid hosts (Diptera) of braconid parasitoids (Hymenoptera) in Brazil. International Journal of Pest Management, v.41, p.208-213, 1995.

NASCIMENTO, A.S.; MATRANGOLO, W.J.R.; BARBOSA, C.J.; MARQUES, O.M.; HABIBE, T.C. Associação de moscas-das-frutas (Diptera: Tephritidae) com a "meleira do mamoeiro" (Carica papaya L.). Anais da Sociedade Entomológica do Brasil, v.29, p.821-825, 2000.

NORRIS, R.F.; CASWELL-CHEN, E.P.; KOGAN, M. Concepts in integrated pest management. New Jersey: Prentice Hall, 2003. $586 \mathrm{p}$.

SALLES, L.A.B. Biologia e ciclo de vida de Anastrepha fraterculus (Wied.).In:MALAVASI, A.; ZUCCHI, R.A.(Ed.).Moscas-das-frutas de importância econômica no Brasil: conhecimento básico e aplicado. Ribeirão Preto: Holos, 2000. p.81-86.

SALLES, L.A.B. Parasitismo de Anastrepha fraterculus (Wied.) (Diptera: Tephritidae) por Hymenoptera, na região de Pelotas, RS. Pesquisa Agropecuária Brasileira, v.31, p.769-774, 1996.

SILVA, J.W.P.; BENTO, J.M.S.; ZUCCHI, R.A. Olfactory response of three parasitoid species (Hymenoptera: Braconidae) to volatiles of guavas infested or not with fruit fly larvae (Diptera: Tephritidae). Biological Control, v.41, p.304-311, 2007.

SOUZA FILHO, M.F. Biodiversidade de moscas-das-frutas (Diptera: Tephritidae) e seus parasitóides (Hymenoptera) em plantas hospedeiras no estado de São Paulo. 1999. 152p. Dissertação (Mestrado) - Escola Superior de Agricultura Luiz de Queiroz, Piracicaba.

WHARTON, R.A.; MARSH, P.M. New World Opiinae (Hymenoptera: Braconidae) parasitic on Tephritidae (Diptera). Journal of the Washington Academy of Sciences, v.68, p.147-167, 1978 .

Received on December 9, 2010 and accepted on May 3, 2011 